\title{
Tackling Salinity in Sustainable Agriculture-What Developing Countries May Learn from Approaches of the Developed World
}

\author{
Sajid Shokat ${ }^{1,2, *(1)}$ and Dominik K. Großkinsky $3,4, *$ (D) \\ 1 Department of Plant and Environmental Sciences, University of Copenhagen, Højbakkegård Allé 13, \\ 2630 Taastrup, Denmark \\ 2 Nuclear Institute for Agriculture and Biology, Faisalabad 38000, Pakistan \\ 3 Department of Plant and Environmental Sciences, Copenhagen Plant Science Centre, Thorvaldsensvej 40, \\ 1871 Frederiksberg C, Denmark \\ 4 AIT Austrian Institute of Technology $\mathrm{GmbH}$, Center for Health and Bioresources, Bioresources Unit, \\ Konrad-Lorenz-Straße 24, 3430 Tulln, Austria \\ * Correspondence: s.shokat@plen.ku.dk (S.S.); dominik.grosskinsky@ait.ac.at (D.K.G.)
}

Received: 29 July 2019; Accepted: 19 August 2019; Published: 22 August 2019

\begin{abstract}
Soil salinity is a common problem of the developing world as well as the developed world. However, the pace to reduce salinity is much slower in the developing world. The application of short-term approaches with an unsustainable supply of funds are the major reasons of low success. In contrast, the developed world has focused on long-term and sustainable techniques, and considerable funds per unit area have been allocated to reduce soil salinity. Here, we review the existing approaches in both worlds. Approaches like engineering and nutrient use were proven to be unsustainable, while limited breeding and biosaline approaches had little success in the developing countries. In contrast, advanced breeding and genetics tools were implemented in the developed countries to improve the salinity tolerance of different crops with more success. Resultantly, developed countries not only reduced the area for soil salinity at a higher rate, but more sustainable and cheaper ways to resolve the issue were implemented at the farmers' field. Similarly, plant microbial approaches and the application of fertigation through drip irrigation have great potential for both worlds, and farmer participatory approaches are required to obtain fruitful outcomes. In this regard, a challenging issue is the transition of sustainable approaches from developed countries to developing ones, and possible methods for this are discussed.
\end{abstract}

Keywords: advanced agricultural approaches; resilience; salinity; salt tolerance; sustainability

\section{Introduction}

Among different stresses, soil salinity is a common problem in arid and semi-arid agricultural regions [1]. All soil in which water-soluble salts exceed $4 \mathrm{dS} \mathrm{m}^{-1}$ is considered saline. Soil salinity and restricted water availability are strongly limiting agricultural production and are predicted to increase considerably during this century [2]. The urban spread is forcing agriculture into drier or more marginal lands, and global food requirements are projected to increase $70 \%$ by 2050 , requiring gains in agricultural productivity on less land area and with lower water input [3]. Although numerous approaches have been introduced, most of these turned out to be unsustainable and/or had only limited success, depending on local conditions. For example, soil salinity is an evenly distributed problem among developing and developed regions (Figure 1) yet, in developed countries, sustainable strategies have been adopted and big areas either reclaimed or replaced with suitable plant genotypes. Moreover, certain grain-producing crops have been extensively investigated and then improved to grow at higher 
levels of salinity. In contrast, in developing countries, short-term soil reclamation approaches have been adopted to tackle salinity, most of which failed and a few of which even increased the level of soil salinity. Likewise, soil health has always been ignored and the biggest area of the world is still being irrigated with saline water, and ultimately, adding salt to soil every year [4]. In contrast, poorly planned short-termed strategies and the use of marginal lands have amplified the risk of salinity [5]. This ever-increasing trend is imprinting a question mark on food security in developing countries. Similarly, the pace to reduce the negative impact of salinity is much slower in developing countries compared to the developed world. It is important and timely to identify and discuss what developing countries can learn from the sustainable approaches of the developed world. This could allow for more suitable and sustainable options to tackle soil salinity and to improve crop production under the saline conditions of the developing countries (Figure 2).

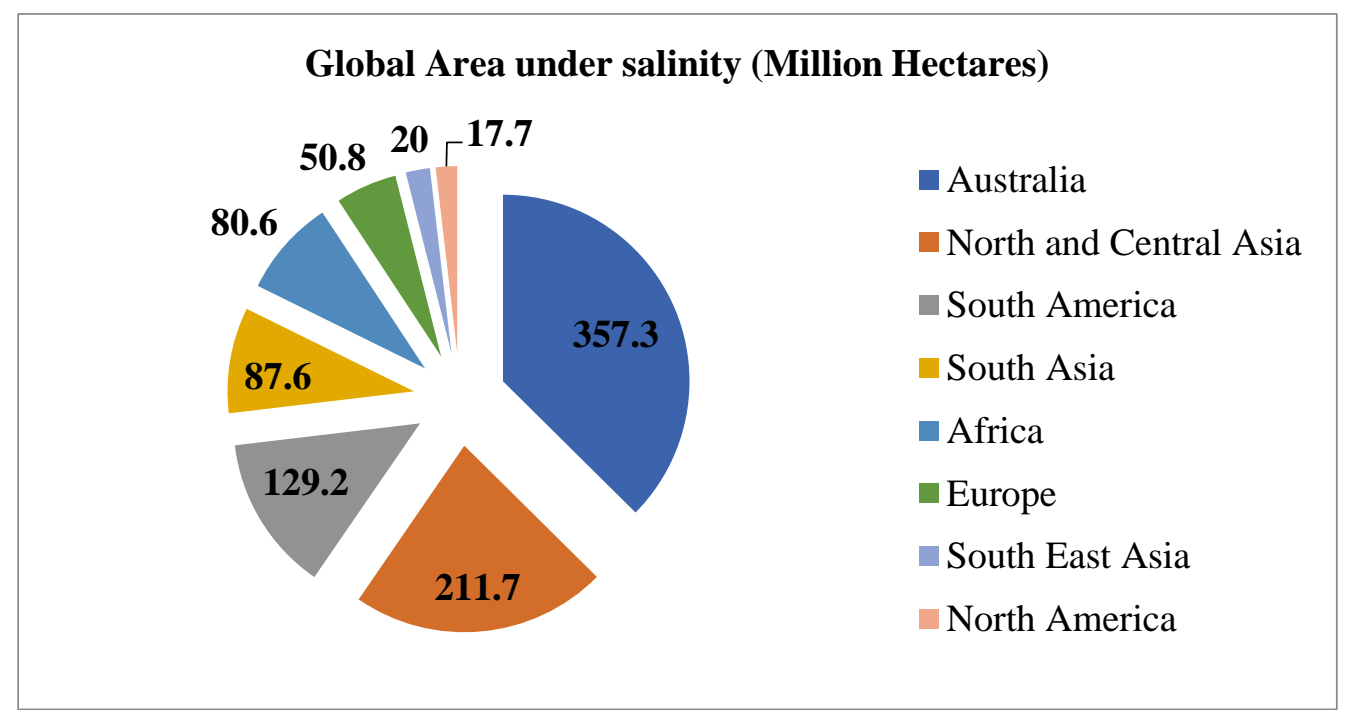

Figure 1. Global distribution of salt-affected areas [6,7].
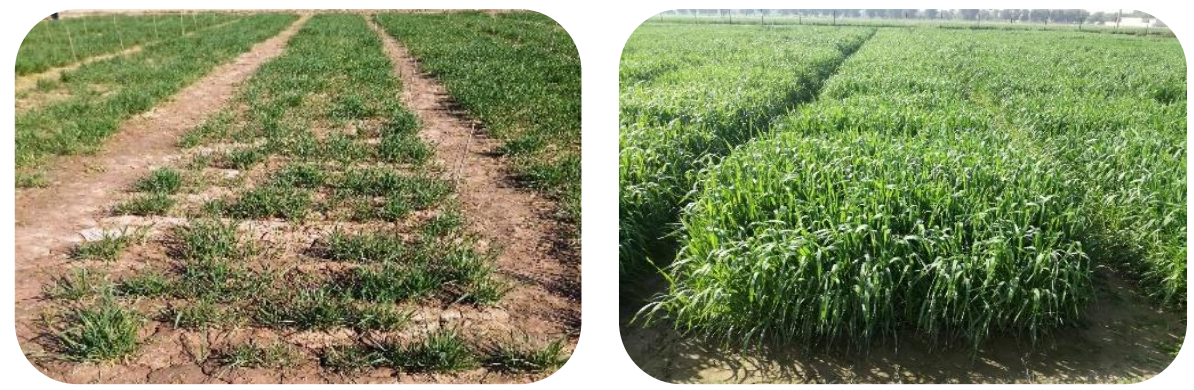

Figure 2. Performance of different wheat genotypes grown under saline (left) and normal (right) conditions.

In this review, we briefly address the general aspects of global areas affected by soil salinity, salinity, and plant interactions. The focus of the review is on the efforts to alleviate the impact of salinity on crops in the developing world in comparison to developed countries, especially what the developing countries can learn from the developed world. In this context, we discuss novel breeding approaches, such as physiological breeding and genome editing, as well as recently emerging management approaches, such as the application of beneficial microbes. Finally, we analyze the overall benefits and potential drawbacks of these approaches, and which approaches will be more sustainable in the future, especially under consideration of the conditions in resource-limited developing nations. 


\subsection{Basic Classification of Salinity}

Previous reports defined soils with salt amounts of more than $0.34 \times 10^{9}$ ha $(23 \%)$ as saline $\left(E C e>4 \mathrm{dS} \mathrm{m}^{-1}\right)$ [8]. Based on severity, the saline area is categorized into four major classes, i.e., very severely saline $\left(E C e>16 \mathrm{dSm}^{-1}\right)$, severely saline (ECe 8-16 $\mathrm{dS} \mathrm{m}^{-1}$ ), moderately saline (ECe $4-8 \mathrm{dS} \mathrm{m}^{-1}$ ), and slightly saline (ECe $2-4 \mathrm{dS} \mathrm{m}^{-1}$ ) [9].

\subsection{Effect of Changing Climate, Underground and Canal Water on the Global Distribution of Salinity}

Harsh climatic conditions, irrigation with unfit groundwater, and an uneven distribution of rainfall are the major contributors for salinity development [10]. A changing climate, with higher temperatures and a bumpy pattern of rains, can cause greater evaporation of water from the soil surface and low leaching of the salts, which could increase the problem of soil salinity. Thus, cultivation in these saline areas largely depends on canal irrigation or underground water. A higher evaporation rate from the soil results in the depositing of a salt layer on the soil surface. There is evidence that the use of canal water deteriorated the agricultural land in Euphrates valley (7000 years ago), and people started to grow more salt-tolerant barley instead of salt-sensitive wheat [11]. Similarly, in other regions of the world, in areas associated with river systems for irrigation, the soils had become saline. For example, the Indus in Pakistan, the Ganges system in the northwest of India, the head-waters of the Mekong river system in the northeast of Thailand, the Huang and associated rivers in the North China plains, the Colorado in the southwest of the USA, the Nile in Egypt, and the Murray-Darling catchments in Australia [12]. It is a fact that canal irrigation water contains sufficient amounts of salts of different kinds to cause soil salinity. It is estimated that the use of water with an electrical conductivity of only $0.5 \mathrm{dS} \mathrm{m}^{-1}$ (with a salt concentration of $0.3 \mathrm{~g} \mathrm{~L}^{-1}$ ) adds enough salt, particularly $\mathrm{NaCl}$, to cause salinity. When soils are insufficiently drained, these salts accumulate in the root zone, and become a great threat to agricultural activities. Likewise, even canal water is not available to every farmer, and consequently, some have to irrigate crops with unfit groundwater, with higher salinity (Figure 3). As a result, the saline area is increasing day by day.

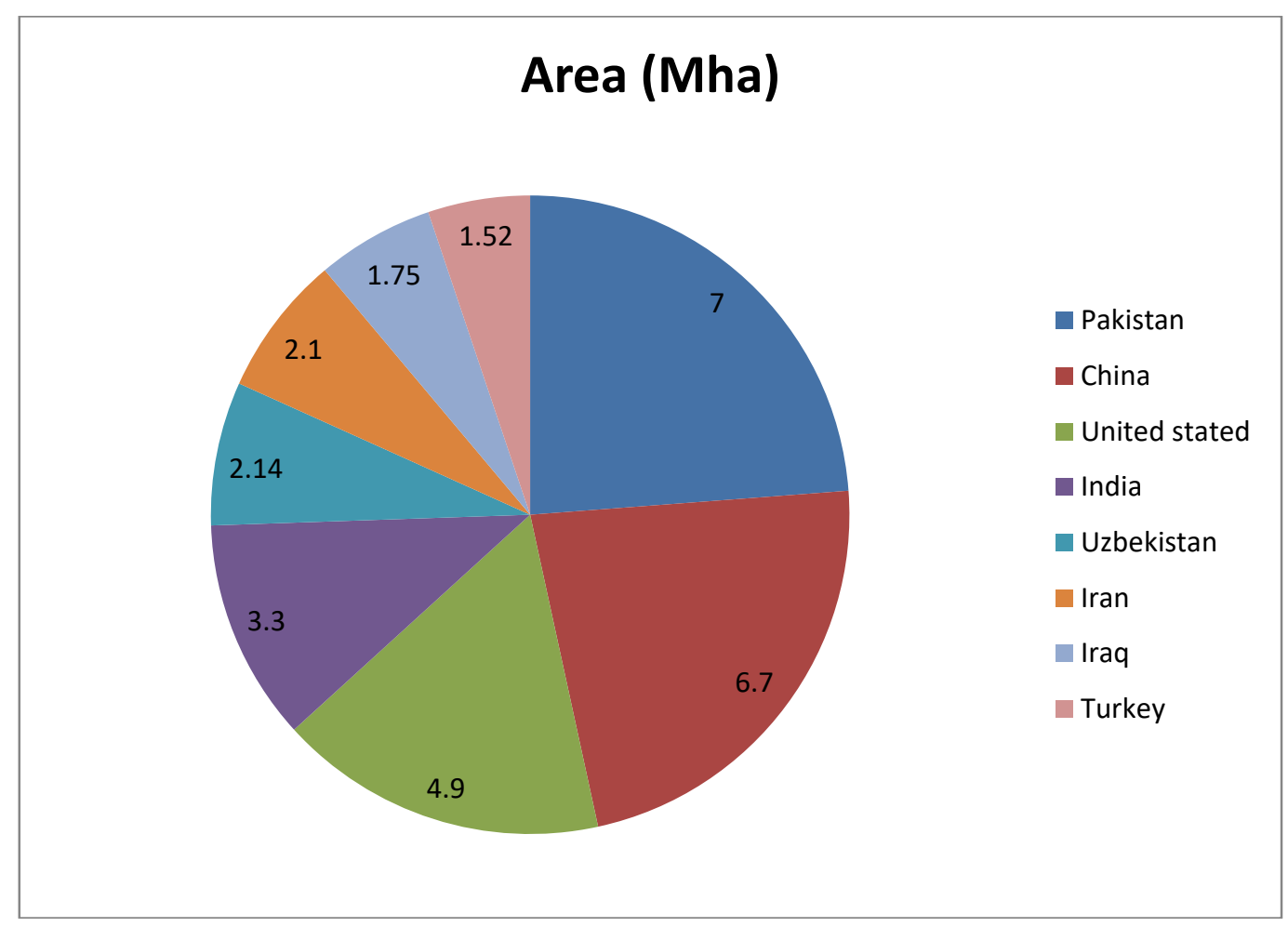

Figure 3. Countries with more than one million hectares of area under saline water irrigation [13]. 


\subsection{Soil Salinity and Plant Interactions}

Salinity is known to affect all plant organs, from roots to leaves. The transportation of ions affects the physiology, anatomy, and overall health of the plant. While mild salt stress can promote root growth [14], high salt concentrations in the root zone may depress the growth of most plant species by lowering the water potential, the excessive accumulation of ions, and the effects of specific ions on metabolic processes, ranging from the absorption of nutrients to enzyme activation [15]. Soil salinity directly reduces the plant water potential [16], which reduces the expansion of leaves, ultimately reduces photosynthesis and proliferation of new tissues and, as a consequence, retards the whole plant growth and production. There are numerous reports on the suppression of photosynthesis as a result of salt stress [17-19]. Several studies revealed that reduced plant growth and decreased yield under stress conditions were due to an unequal supply and impairment in essential nutrient elements and water deficit, abnormal metabolism, and the improper synthesis of proteins [20-22].

Apart from yield, the quality of the harvest product is a key parameter in agricultural production. Quality parameters of fleshy fruits, such as strawberry (Fragaria ananassa Duch.), tomato (Solanum lycopersicum L.), watermelon (Citrullus lanatus L.), or pepper (Capsicum annuum L.), can be improved by increased salt concentrations in growth substrates [14,23-26]. The enhanced accumulation of different soluble compounds, which are described as important fruit quality parameters, could be considered as an "enrichment effect", as fruit yield is limited at the same time. Also, the negative impact of salinity on reducing fruit yield by promoting physiological disorders, such as blossom end-rot, has been shown in different crops [26,27]. Similarly, grain quality parameters of important cereal crops, such as wheat (Triticum durum Desf. and Triticum aestivum L.) [28-30], rice (Oryza sativa L.) [31], or corn (Zea mays L.) [32], could be improved by applying salinity, depending on the specific conditions and cultivars. However, decreased wheat $[30,33]$ or rice [34] grain quality in addition to yield decline under salt stress conditions has also been reported.

The process of maintaining cell turgor initiated by plants by increasing cell solutes to compensate for external osmotic stress is described as osmoregulation, osmoprotection, osmotic compensation, or osmotic adjustment [35]. Osmoregulations in higher plants under salt stress depends either on the reduced uptake of salts, the synthesis of organic solutes, or both. In plants, the major osmoregulators or osmoprotactants are glycine betaine, proline, and polyols [36]. These changes help plants to complete their life cycle under salt stress.

\section{Efforts to Alleviate Salinity Impact on Crops in Developing Countries}

Diverse approaches to tackle soil salinity have been followed in different developing countries; however, the outcomes were not sustainable. Mostly, short-range solutions were executed to solve this difficult task and, in most of the developing countries, saline water is used for irrigation (Figure 2). For example, Pakistan is predominantly an agricultural country, and a major part of the agricultural area is commanded by an extensive canal irrigation system. The continuous use of low-quality canal and underground irrigational water affects about $5.7 \times 10^{6}$ ha of arable land within the country [37]. This practice has caused $0.6 \times 10^{6}$ ha to be slightly saline, $1.23 \times 10^{6}$ ha to be moderately saline, $2.385 \times 10^{6}$ ha to be severely saline, and $2 \times 10^{6}$ ha very severely saline areas [38]. This distribution of saline area presents the progression of salinization in such countries and has become a threat to agriculture. A very serious and prolonged effect of this soil-related irrigation is causing desertification, which affects both the developed and developing world, to different degrees. This is clearly a major threat to food security in the overpopulated areas, particularly in India, Bangladesh, and Pakistan [39].

\subsection{Engineering Approaches}

A few drainage projects have been introduced to tackle the salinity in waterlogged areas of the developing world. Likewise, several measures to reclaim the huge acreage were using gypsum, Sulphur, and sulphuric acid, which accelerated the leach down the salts present in the root zone [40]. In 
addition to a chemical approach, tube wells were installed under the Salinity Control and Reclamation Project (SCARP) in waterlogged areas of Pakistan [41] and a hydrological approach in India [42-45]. Although these approaches were effective in decreasing the concentration of salt to some extent, they became uneconomical for the developing countries due to the escalating costs of labor, energy, and chemicals. Secondly, these drainage projects lowered the water table to a great extent, and the threat to search the alternative water resources increased with the passage of time.

\subsection{Conventional Breeding (Limited Efforts)}

Since the development of the civilized world, plant domestication and selection has been proven to be the more suitable option for global food security among different nations of the world. It has helped people to ensure food security. Plant scientists many years ago started to exploit plants' genetic resources for developing crop cultivars tolerant to soil salinity. The success stories of breeders provided impetus to other breeders for bringing genetic modifications in plant species endemic to the area affected by salinity. Different varieties of T. aestivum, Hordeum vulgare L., Gossypium barbadense L., and O. sativa were developed for high yields in saline regions of Pakistan, India, and Egypt. These varieties were also found to be suitable for non-saline areas $[46,47]$ like Kharchia-Rata, a T. aestivum line in India, Sakha-8 in Egypt, and LU-26S and SARC-I in Pakistan [48], the O. sativa variety Giza-159 [49] and G. barbadense cultivars, Bhatim-108 and Bhatim-110 [50], and in Pakistan cultivars of Gossypium hirsutum L. NIAB-78 [51,52] and MNH-93 [52], were found to be most tolerant to soil salinity.

Although the breeding of plants for salt tolerance is considered most economical, it depends on a long-term commitment. However, no continuity has been seen to develop cultivars based on new breeding approaches. Numerous studies in different crops have been conducted at an academic level [53-55], but the final product relevant for agricultural use is missing. Likewise, most of the potential developed genotypes with tolerance to certain stressors are being sent through different international organizations, such as the International Maize and Wheat Improvement Centre (CIMMYT), Mexico, International Rice Research Institute (IRRI), Philippine, International Center for Agricultural Research in Dry Areas (ICARDA), Syria, and International Crops Research Institute for the Semi-Arid Tropics (ICRISAT), India, but these centers have very little or no focus on breeding for the salinity tolerance of these crops. Similarly, no breakthrough was achieved in any other crop, as only small-scale and short-term studies were conducted for most of the crops.

\subsection{Unsustainable Efforts on Biosaline Approaches}

Salt tolerant plant species, which can grow on saline water, are grown on saline soils. Salt marshes, salt swamps, inland saline sweeps, and saline deserts are salt-rich in nature and are known to be natural sources of salinity, and the plants growing there show evidence of their ability to survive under these adverse and severe conditions of salinity, for example, Atriplex hastata L., Salicornia europaea L., Eucalyptus camaldulensis Dehnh., Spartina townsendii H.J., and Distichlis spicata L. have shown adaptation to high salt concentrations, and they complete their life cycle without being affected by salinity [56]. A considerable number of projects have addressed the potential of these shrubs and trees in developing countries, but most of them were finished with little success, mainly due to a lack of continuous funding. One of those projects was the plantation of E. camaldulensis in Asia to mitigate waterlogging and salinity [57]. However, this approach failed in semi-arid areas, as insufficient water was available to grow Eucalyptus. This plant species not only utilizes water at a higher pace but also depletes the soil nutrients [58]. The SAFPDP project with an integrated biosaline approach was started in Pakistan and the Philippines in collaboration with Australia. The success of this project was significant, however, this project was ended by a lack of funds [59].

\subsection{Nutrient Management}

Nutrient management of crop plants is being used to ameliorate the level of salinity tolerance. The amendment of different nutrients to cope with salinity stress is also a part of fertilizer research in few 
countries. Studies have indicated that sensitive crop species have shown significant tolerance through the use of selective nutrients. A few nutrients have the potential to abate the severity. Previous studies on salt tolerance revealed that the adverse effects of salinity, in the presence of macronutrients in the soil, are less drastic. Numerous studies showed that the presence of NPK in saline soils stimulated plant growth and increased the lint yield of G. hirsutum [60], C. annum [22], and S. lycopersicum [61]. Sodium disrupted the potassium (K) uptake in most of the saline soils [62], likewise, calcium (Ca) is an important determinant of plants under salt stress and acts as a second messenger in stress signaling [63]. This indicates that both $\mathrm{K}$ and $\mathrm{Ca}$ are necessary nutrients for normal plant growth and the provision of these two nutrients can help plants to survive under salt stress conditions. Different studies showed that these nutrients improved the plant biomass as well as the grain yield. Results from Z. mays hybrids by Abbasi et al. [64] suggested that high levels of soil salinity were efficiently mitigated by the application of K. Similarly, Yousuf et al. [65] manifested that high salinity can be tackled by high levels of $\mathrm{K}$ and Ca in Brassica napus L. Likewise, Rashid et al. [66] identified that most of the calcareous soils of Pakistan are deficient in boron (B), while the application of this element would be effective in combating salinity. Abid et al. [67] demonstrated that Na concentration was decreased in B. napus. straw by the application of B. Parallel to the other nutrients, silicon is considered a minor nutrient for plant growth and plants can complete their lifecycle without it. Yet, under salt stress it has an important contribution and Abdel-Haliem et al. [68] reported that silicon upregulated the plant phytohormones, especially jasmonic acid (JA), in rice grown under salt stress and it further activated the antioxidants and osmolyte production.

Despite the great potential of nutrient application for coping with the effects of soil salinity, only small success has been observed in field applications. One of the major problems is the availability of scarce resources. Typically, farmers either have only small land holdings with a limited budget or do not have enough water to irrigate their crops. Obviously, it is very hard for them to apply nutrients along with chemical fertilizers and consequently, no significant contribution has been observed.

\section{Approaches from the Developed World}

In comparison to the developing world, more sustainable approaches were evolved and implemented in the developed countries. More focus was given to plant species and their management in response to soil salinity levels. Recent microbial and molecular tools were identified, and both plant and soil were successfully engineered. Potential approaches were tested and implemented at farmers' fields to get the better reward.

\subsection{Physiological Breeding}

In contrast to specific qualitative and quantitative traits aimed at conventional breeding, more complex physiological plant traits may be promising novel targets in breeding and agricultural management practices. As developmental and environmental cues are integrated at the physiological level, physiological breeding targets may allow for improving plasticity under varying conditions, which subsequently stabilizes yield [69]. Physiological breeding can play an important role in identifying plants tolerant to abiotic stress. Several studies have demonstrated salt tolerance mechanisms, however, ion accumulation [70-72], ion exclusion [52,73], and osmotic adjustment $[74,75]$ are the most common mechanisms of salt tolerance in most of crop species.

A well-developed mechanism of osmotic adjustment is found in halophytes. Their ability to synthesize more organic compounds, such as glycerol, mannitol, sorbitol, and proline supports them in reducing the effects of dehydration and salinity [76]. Proline and glycine betaine have been found to decrease the toxic effects of salinity caused by $\mathrm{NaCl}$ [77]. To avoid dehydration and to maintain turgor, the cell must decrease total water potential by reducing osmotic potential. The primary responses of almost all the agricultural crops (commonly known as glycophytes) to salinity are the restricted transport of the salt to the shoots and the maintenance of a favorable water balance by the synthesis of organic solutes [78]. In order to survive, the plant must adjust osmotically by building up even higher 
internal solute concentrations. Organic solutes, such as proline, sugars, and glycine betaine are the main organic osmoregulators in glycophytes, which protect them from adverse effects of salinity $[36,78]$. In the presence of these organic substances, plants become able to accumulate high levels of salts, maintain the soil-water balance, and can grow under high salt concentrations [79,80].

Crop resilience to changing levels of soil salinity has improved and the combination of agro-physiological traits has successfully been utilized to breed different crop species in developed countries (Table 1). Consequently, a number of crop species have been released and are performing well the farmers' fields. The incorporation of a few of the above-mentioned traits with positive associations with agronomic parameters can help the plant breeders to develop a better ideotype of crops.

Table 1. Crops improved against soil salinity using physiology breeding.

\begin{tabular}{cccc}
\hline Crop Species & Physiological Traits & Traits & Reference \\
\hline Oryza sativa & Glycine Betaine & $\begin{array}{c}\text { Quantum yield of PSII } \\
\text { under salinity }\end{array}$ & Harinasut et al. [81] \\
Nicotiana tabacum & $\begin{array}{c}\text { Glycine betaine, proline, } \\
\text { mannitol, and Sorbitol }\end{array}$ & Salinity tolerance & Rontein et al. [36] \\
Triticum aestivum and & Higher $\mathrm{K}^{+}$around root \\
Triticum durum & zone & Plant biomass and yield & Cuin et al. [82] \\
Gossypium hirsutum & $\begin{array}{c}\text { Higher } \mathrm{K}^{+} / \mathrm{Na}^{+} \text {ratio, and } \\
\text { proline accumulation } \\
\text { Water Use Efficiency, }\end{array}$ & $\begin{array}{c}\text { Better performance at } \\
\text { higher salinity levels }\end{array}$ & Nabi et al. [54] \\
Miscanthus $x$ giganteus & stomatal conductance, and \\
leaf water contents & Plant Biomass & Stavridou et al. [83] \\
Triticum aestivum and & Higher proline within roots, \\
Hordeum vulgare & and osmotic adjustment & better performance at \\
salinity & Darko et al. [84] \\
\hline
\end{tabular}

\subsection{Genome-Wide Associations for Marker-Trait Associations}

In the genomic era, whole genome sequencing combined with the development of statistical methods led to the emergence of genome-wide association studies (GWAS) as a powerful tool to describe the associated variation [85], which increasingly contributes to the advancements in modern crop research. Likewise, Gabriel et al. [86] demonstrated that GWAS, along with haplotype frameworks, provides substantial statistical power in marker traits association studies and provides a foundation for the construction of a haplotype map, which may be helpful for studying rare variation [87]. This technology is becoming cheaper and the rewards are long term. Brachi et al. [88] reported that GWAS is even more powerful in plants as compared to human research. In recent years, several GWASs addressed salinity tolerance in different crops. Early responses in plant growth and transpiration can be tracked using this approach [89]. Different complex traits have been investigated successfully with GWAS and a number of useful regions have been incorporated within crop plants. In model plants like Z. mays, GWAS is not only helpful for cloning the genes but has also proposed certain new genes for complex traits [90]. Next-generation sequencing approaches have paved the way for associating genotypic and phenotypic data with minimum errors. These approaches are helpful for studying the salinity responses of different crops during the growth or postharvest stages.

One of the major debates surrounding growing crops in saline areas is the quality of their grains or harvest products. A focus does exist on postharvest research of these crops. However, in the developing countries where the grains are the staple foods, this is rarely studied. In recent years, studies were conducted to understand the genetics of grain quality grown under adverse environments. Developed countries have already made major progress and numbers of genomic regions have been identified to be associated with protein and starch contents. Likewise, free amino acids (FAAs) serve as an alternative source of energy. Angelovici et al. [91] stated that manipulation FAA can significantly impact the nutritional qualities of grains and through GWAS the genes coding for free amino acids can be identified. Liu et al. [92] identified four candidate genes for kernel starch and expressed that 
these genes can also elucidate the genetic basis of starch content. Similarly, with the advancement in analytical techniques and tools, the identification of qualitative traits has become cheaper.

\subsection{Transgenes and Genome Editing}

To serve the purpose, numbers of genes have been incorporated, bypassing the conventional crossing for the improvement of certain crops. Few genes conferring tolerance to soil salinity have been incorporated in the cultivated crops. The most common approach was the transformation with Nax1 and Nax2 [93,94]. These genes could exclude toxic ions and this exclusion capacity is useful for improving salinity tolerance as it results in less injury to the cells.

A few other genes have also been identified to maintain a higher ratio of $\mathrm{K}^{+} / \mathrm{Na}^{+}$within the cells. Among these, AtHKT derived from Arabidopsis thaliana (L.) Heynh. mediates the loading and unloading of $\mathrm{Na}^{+}$. AtNHX1 plays a role in $\mathrm{pH}$ maintenance and/or $\mathrm{K}^{+}$homeostasis in specialized cells [95] and the overexpression of AtNHX1 has been proven to ameliorate the $\mathrm{Na}^{+}$toxicity in $A$. thaliana and study of this model species indicates such genes can improve tolerance of field crops [96]. Xu et al. [97] reported that Petunia hybrida Juss., with an over-expression of AtNHX1, has maintained higher water content, more proline, and higher $\mathrm{K}^{+} / \mathrm{Na}^{+}$ratio within the plants. Pyramiding of these genes within the cop plants will improve the plasticity to varied range of soil salinity (Table 2). Such approaches may facilitate the breeders of developing nations to improve the salinity tolerance of crops.

Different monogenic traits have been improved through genome editing, either by deletion or gene duplication [98,99], by the advent of techniques like engineered endonucleases, zinc finger nucleases (ZFNs), transcription activator-like effector nucleases (TALENs), and clustered regularly interspaced short palindromic repeat (CRISPR)/CRISPR-associated protein 9 (Cas9). Each technique has some limitations over the other. However, CRISPR-Cas9 looks more promising, with minimum limitations, and the development of climate-smart crops appears realistic. Four wild accessions of tomato were improved without losing the genetic diversity for disease resistance and salinity tolerance [100]. Likewise, Zsögön et al. [101] improved wild species of tomato (Solanum pimpinellifolium L. (Mill)) by editing six loci of tomato, which resulted in an improvement in the yield fruit size and five-times increase in lycopene contents. Similarly, Sánchez-León et al. [102] modified 35 genes out of 45 reported genes responsible for high gluten, and developed low-gluten wheat using this approach. These findings indicate that traits like disease resistance and drought tolerance have been improved [103] and tolerance to salinity in grain crops can be enhanced by using CRISPR-Cas9 in combination with other plant breeding approaches.

Table 2. Crops improved against soil salinity using transgenes.

\begin{tabular}{|c|c|c|c|}
\hline Transgene & Plant Species & Physiological Improvement & Reference \\
\hline Nax1 & Triticum durum & $\mathrm{Na}^{+}$was removed from the $x y l e m$ & James et al. [104] \\
\hline $\operatorname{Nax} 2$ & Triticum durum & $\begin{array}{l}\text { Plants did not retain } \mathrm{Na}^{+} \text {within the } \\
\text { leaf and } \mathrm{Na}^{+} \text {functioned only in the root }\end{array}$ & James et al. [104] \\
\hline AtNHX1 & Petunia hybrida & $\begin{array}{l}\text { Maintained higher water contents, } \\
\text { proline and higher } \mathrm{K}^{+} / \mathrm{Na}^{+} \text {ratio }\end{array}$ & Xu et al. [97] \\
\hline AKT1 & Arabidopsis thatiana & $\mathrm{K}^{+}$channel is expressed in roots. & Hirsch et al. [105] \\
\hline AKT2 & Arabidopsis thatiana & Expressed in the leaf phloem tissue. & Deeken et al. [106] \\
\hline SOS1 & $\begin{array}{l}\text { Triticum durum } \\
\text { Triticum aestivum }\end{array}$ & $\begin{array}{c}\text { Extrusion of } \mathrm{Na}^{+} \text {from roots to } \\
\text { external zones }\end{array}$ & Wu et al. [107] \\
\hline CIN & Solanum lycopersicum & $\begin{array}{c}\text { Increased in sucrolytic activities (cwInv, } \\
\text { sucrose synthase, and vacuolar, and } \\
\text { cytoplasmic invertases), and decreased } \\
\text { in the } \\
\text { 1-aminocyclopropane-1-carboxylic acid } \\
\text { (ACC) activity }\end{array}$ & Albacete et al. [108] \\
\hline
\end{tabular}




\subsection{Microbial Approaches}

Novel approaches in fundamental science and agriculture target utilizing diverse beneficial microbes to improve plant growth and stress resilience [109], including increased tolerance to salt stress. Both bacteria and fungi have been shown to enhance plant tolerance to salinity. The inoculation with one of the best-studied endophytic root fungi, Piriformospora indica, resulted in an enhanced tolerance of rice (O. sativa), barley (H. vulgare), and clover (Medicago truncatula Gaertn.) to salt stress [110-112]. In these plant species, $P$. indica inoculation resulted in an increased biomass accumulation under salinity, which correlated with the elevated activities of key antioxidant enzymes [110-112] and increased levels of proline as osmoprotectant in rice and clover $[110,112]$. The proteomic analysis of $P$. indica-inoculated barley allowed for the identification of more than 50 proteins of diverse functions, including photosynthesis, antioxidants, and signal transduction, which correlated with improved salt tolerance [113]. Similarly, diverse bacteria have been shown to improve salinity tolerance in different plants. A Pantoea agglomerans isolate of the corn ancestor teosinte improved salt tolerance in a tropical corn variety, evidenced by increased biomass under salinity, which correlated with the up-regulated expression of aquaporin genes, which may contribute to the observed salt tolerance [114]. Inoculation with the plant growth-promoting bacteria Achromobacter piechaudii and Sphingomonas sp. alleviated salt stress in tomato $[115,116]$. A. piechaudii-mediated salt tolerance correlated with its ACC deaminase activity, by which increased ethylene production in the salt-stressed plants was counteracted [115], while Sphingomonas inoculation affected the levels of proline, glutathione, and the phytohormones abscisic acid (ABA), jasmonic acid (JA), and salicylic acid (SA) in salt-stressed plants [116]. Various phytohormones are critically involved in regulating plant growth and tolerance or resistance towards biotic and abiotic stresses $[117,118]$. Therefore, especially the modulation of phytohormone homeostasis and signaling of the host plant by beneficial microbes, either by microbial phytohormone production or by regulating the host's phytohormone balance, is a promising approach for future strategies to improve crop cultivation, including the alleviation of salt stress. Pseudomonas isolates producing the auxin indole-3-acetic acid (IAA) have been shown to improve the germination and growth of wheat and cotton under salinity stress $[119,120]$. In addition, these strains increased the resistance of cotton plants to infection with the fungal pathogen Fusarium [120]. Also, ABA-producing Bacillus amyloliquefaciens improved the salt tolerance of rice plants [121]. Similarly, different species of the fungal endophyte Penicillium enhanced salinity tolerance in soy, tomato, and pepper by their GA production [122-124], which also conferred heat and drought tolerance to pepper plants [124].

Salt tolerance mediated by beneficial microbes has been shown in diverse plant species, which was based on different underlying mechanisms. The variety of mechanisms can be challenging when trying to define a specific treatment in relation to a distinct mode-of-action. However, this variety-in combination with the wide range of microbes that have been demonstrated to improve salt tolerance-is also a promising basis for developing tools for specific stress scenarios and individual plant species. Mechanisms such as the microbial production of phytohormones, e.g., cytokinins, may offer additional potential to combine the improved tolerance to salt stress with other beneficial effects $[125,126]$ such as improved drought tolerance [127], resistance to pathogens [126,128], and growth promotion $[129,130])$. Increasing understanding of their modes-of-action and their robustness under different environmental conditions may serve as a basis for cost-effective and ecologically-friendly microbe-based strategies $[109,131,132]$ to alleviate salt stress by improving the stress resilience of crop plants, potentially in combination with additional beneficial effects, as tools for sustainable agriculture [133].

\subsection{Effective Fertigation to Tackle Salinity}

Soil salinity is increasing farmers' fields due to the injudicious use of irrigations and improper use of fertilizers [134]. However, the use of better irrigation systems, along with balanced fertilizers with alternatives to sodium $\left(\mathrm{Na}^{+}\right)$, chloride $\left(\mathrm{Cl}^{-}\right)$, or sulphate $\left(\mathrm{SO}_{4}{ }^{2-}\right)$ ions, can minimize the chance of soil salinity. The use of humic acid and phosphorus $(\mathrm{P})$ has been practiced in beans by Aydin et 
al. [135] and Bargaz et al. [136], respectively, to mitigate the effect of soil salinity. Bacilio et al. [137] reported that humic acid increased the ratio of $\mathrm{Ca}^{2+} / \mathrm{Na}^{+}$and $\mathrm{K}^{+} / \mathrm{Na}^{+}$in pepper grown under salinity. Likewise, the use of $\mathrm{KNO}_{3}$ fertilizer in melon has effectively improved the melon production under saline soils [138]. Martinez and Cerdá [139] reported that the presence of nitrates $\left(\mathrm{NO}_{3}{ }^{-}\right)$could reduce the uptake and accumulation of $\mathrm{Cl}^{-}$in cucumber. Moreover, salicylic acid was reported to be effective for tomato, strawberry, and zucchini squash by Romero-Aranda et al. [140], Karlidag et al. [141], and Savvas et al. [142], respectively. Ma et al. [143] reported that the exogenous application of salicylic acid has improved photosynthesis, the activity of antioxidants, and the development of chloroplasts in Dianthus superbus L.

Few of the above-mentioned fertilizers can effectively be utilized in combination by mixing with water. This type of irrigation is also called fertigation, however, salinity is usually raised in fields when fertilizers are injudiciously dissolved in water. Due to the inherent potential of the soil, the evaporation of moisture occurs, leaving behind the fertilizers in the form of salts [144]. Malash et al. [145] reported that surface and sub-surface drip fertigation can minimize the effect of salinity. It makes the soil moist throughout the plant growth, leaving behind the risk of salinization and sub-surface irrigation is even more promising [146]. The application of these techniques can be helpful to counter salinity and can promote water use and nutrient use efficiency.

\section{Limitations of Current Approaches, Potential of Approaches in the Developed World, and Their Challenges}

Each developing country has different constraints to control soil salinity. However, a lack of funds is common among all. Approaches depending on a high energy consumption are difficult to realize in countries with energy shortages. Likewise, biosaline approaches are a good option to ameliorate soil salinity and to grow crops later, but a lack of funds is a major constraint for sustainable development. Nutrient management also implies costs for the farming community and farmers with small land holding cannot meet the expenses of such chemicals. Conventional breeding offers promising solutions, but it also requires long-term commitment to find appropriate plant material with plasticity to higher salinity.

A few lessons can be learned from the developed world. Areas with high salinity can be covered with halophytes or glycophytes with low water requirements. Plant breeders equipped with diverse tools can rightly breed crop varieties to grow the crops at certain levels of soil salinity. Tolerance to soil salinity varies among crops; however, plant scientists of developing countries can use certain established physiological markers to evaluate their germplasm at different levels of salinity. The availability of genotypic data along with computerized software is helpful to associate certain plant traits, which may put certain breeding strategies on the right path to ameliorate soil salinity problem (Figure 4). Likewise, products grown in these areas should be tested for their fitness for human or animal consumption. Quality analysis coupled with GWAS will be helpful for the plant scientists of the developing world to give their products better quality (Table 3).

Selective approaches can be implemented in the selective areas for sustainable growth in the developing world. A few of these countries have the necessary resources but a lack of technical expertise. The provision of practical training will be helpful to execute the plans into the right direction. Likewise, recent advancements look promising, and fertigation through sub-surface drip irrigation and microbial approaches have the potential for both worlds. Farmers 'participatory projects through research-extension services can promote the farmers to test these developed products in their fields. Moreover, keeping in view the tradition and education of the selective areas, a sustainable focus at governmental level is required to get the desired results. 


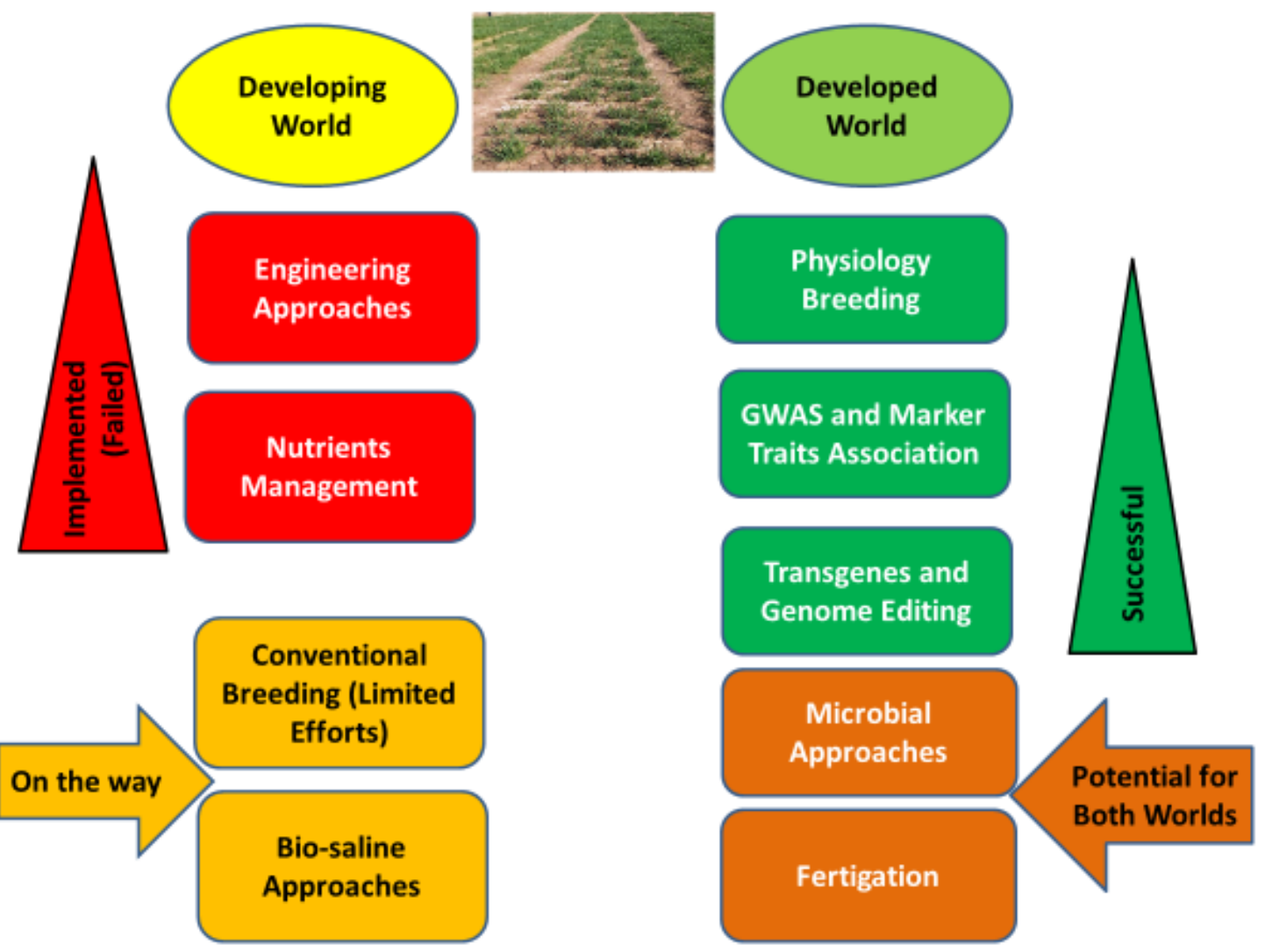

Figure 4. Illustration of approaches in the developing and the developed world. Approaches implemented in the developing countries largely failed (red), while other approaches are not consistent (orange). Approaches successfully implemented in the developed world (green) and emerging approaches (brown) are promising for potential implementation to alleviate the impact of salinity in developing countries for sustainable development.

Table 3. Status, potential benefits, and limitations of approaches to cope with salinity in the developing and developed world.

\begin{tabular}{|c|c|c|c|}
\hline Approaches & Status & Expectation/Potential Benefits & Limitations \\
\hline \multicolumn{4}{|c|}{ Developing world } \\
\hline $\begin{array}{l}\text { Engineering approaches } \\
\text { - Chemical approach } \\
\text { - Hydrological approach }\end{array}$ & Closed & $\begin{array}{l}\text { Swift to cure soil from salinity } \\
\text { and water-logging }\end{array}$ & $\begin{array}{l}\text { High cost of chemicals, labor, } \\
\text { and energy. } \\
\text { Increased the level of } \\
\text { chemicals and lower the } \\
\text { water table }\end{array}$ \\
\hline Conventional breeding & On-going & $\begin{array}{l}\text { Salt tolerant crop plants will } \\
\text { ensure enough production }\end{array}$ & $\begin{array}{c}\text { Less diversity } \\
\text { Flimsy research at } \\
\text { international organizations } \\
\text { of agriculture }\end{array}$ \\
\hline Bio-saline approach & Closed & $\begin{array}{l}\text { Diverse options to tackle salinity } \\
\text { at farmers' fields }\end{array}$ & $\begin{array}{l}\text { Lacking continuous supply } \\
\text { of funds }\end{array}$ \\
\hline Nutrient management & Scanty use & $\begin{array}{c}\text { Acclimation of crop plants at } \\
\text { saline areas }\end{array}$ & $\begin{array}{l}\text { Challenging to convince } \\
\text { farmers }\end{array}$ \\
\hline
\end{tabular}


Table 3. Cont.

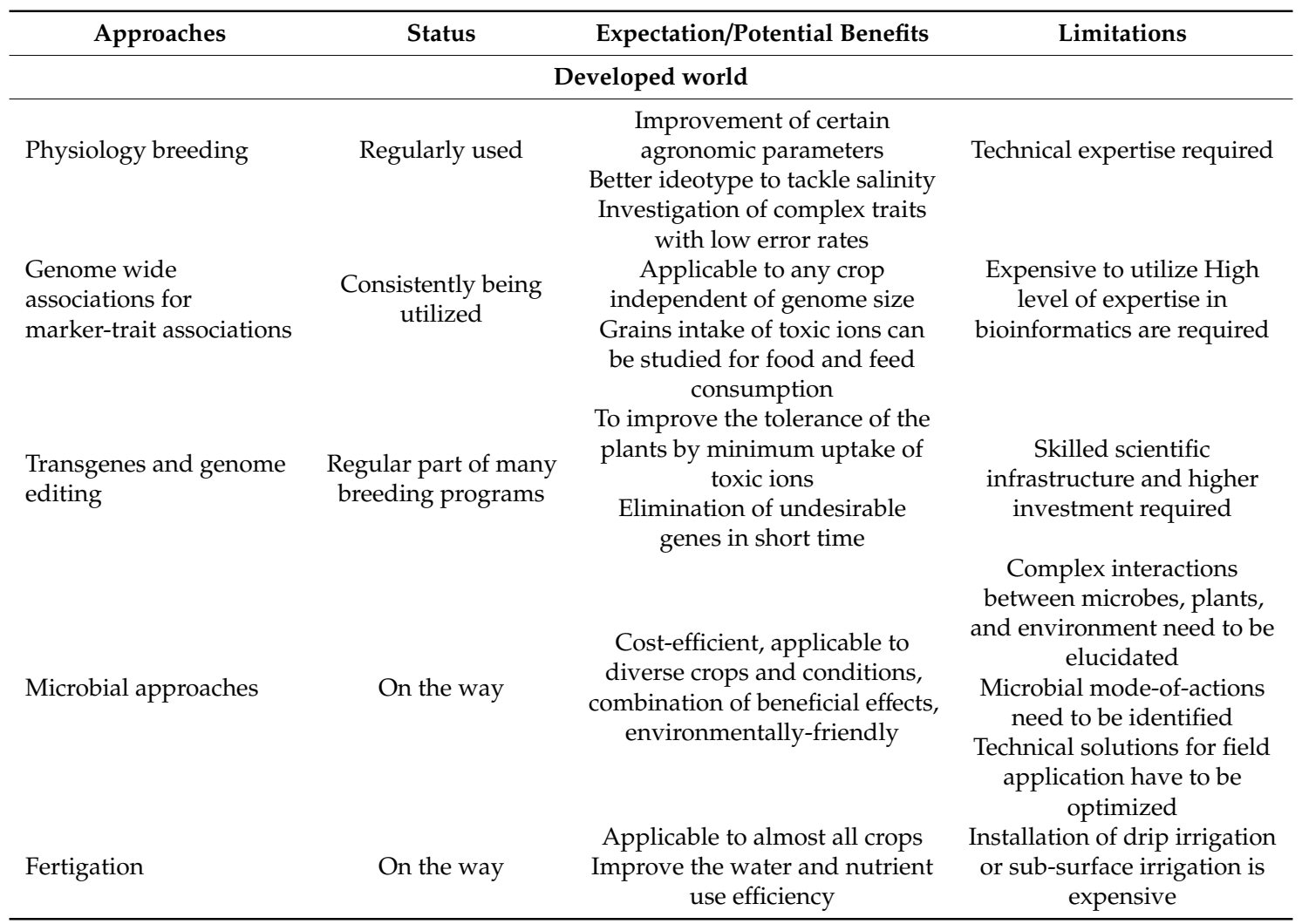

\section{Conclusions}

Soil salinity is causing a great threat to global food productivity, leading to similar basic challenges in cultivating crops in a sustainable manner under saline conditions in developing and developed countries. While some of the approaches implemented in the developed world successfully reduced the negative impact of salinity on crop cultivation and emerging approaches show promising initial results, the success of coping with salinity in developing countries has been strongly limited. A sustainable development can be made, keeping in view the resources, technical expertise, infrastructure, and traditions of each country. Approaches like transgenes and genome editing can be beneficial, as they improve the physiology of the plants, and hence the performance under salinity. The provision of plant genotypes with such genes will help the breeders of developing countries to incorporate these traits into their own germplasm. Likewise, GWAS application can be helpful to find marker traits associations both for pre-harvest and postharvest stages. Similarly, gene editing techniques can be helpful for removing undesirable genes of cultivated and wild plant species. Furthermore, the application of beneficial microbes and fertigation through drip irrigation in collaboration with farmers will push the farming community to utilize their available resources to keep their self-sufficiency in food and agro-based products.

Author Contributions: S.S. conceived the basic idea of the review. S.S. and D.K.G. designed the structure of the review. Both authors wrote and revised the review. S.S. developed illustrations and the corresponding figures with feedback provided by D.K.G. Both authors approved the final version of manuscript.

Funding: Islamic Development Bank Saudi Arabia.

Conflicts of Interest: The authors declare that they have no conflict of interest. 


\section{References}

1. Ahmed, M.Z.; Gul, B.; Khan, M.A.; Watanabe, K.N. 1-Characterization and Function of Sodium Exchanger Genes in Aeluropus lagopoides Under $\mathrm{NaCl}$ Stress. In Halophytes for Food Security in Dry Lands; Academic Press: Cambridge, MA, USA, 2016; pp. 1-16.

2. Jamil, A.; Riaz, S.; Ashraf, M.; Foolad, M.R. Gene Expression Profiling of Plants under Salt Stress. Crit. Rev. Plant Sci. 2011, 30, 435-458. [CrossRef]

3. Fischer, G.; Hizsnyik, E.; Prieler, S.; Wiberg, D. Scarcity and Abundance of Land Resources: Competing Uses and the Shrinking Land Resource Base. In Proceedings of the Worlds Within Reach: From Science to Policy-IIASA 40th Anniversary Conference, Laxenburg, Austria, 24-26 October 2012.

4. Alam, S.M.; Ansari, R.; Khan, M.A. Saline agriculture and Pakistan. Ind. Econ. 2010, 21, 21.

5. NSW. Office of Environment \& Heritage; All about salinity: Sydney, Australia, 2002; pp. 10-22.

6. Szabolcs, I. Soil Salinity and Sodicity as Particular Plant/Crop Stress Factors. In Handbook of Plant and Crop Stress, 2nd ed.; CRC Press: Boca Raton, FL, USA, 1993.

7. Khan, A.A.; McNeilly, T.; Azhar, F. Stress Tolerance in Crop Plants. Review: 3. Int. J. Agric. Biol. 2011, 3, 250-255.

8. Tanji, K.K. Nature and Extent of Agricultural Salinity. In Agricultural Salinity Assessment and Management; Anuals and Reports on Engineering Practices; Tanji, K.K., Ed.; American Society of Civil Engineers: New York, NY, USA, 1990; pp. 1-18.

9. Dornburg, V.; Vashev, B.; Turkenburg, W.; Wicke, B.; Smeets, E.; Gaiser, T.; Faaij, A. The global technical and economic potential of bioenergy from salt-affected soils. Energy Environ. Sci. 2011, 4, 2669.

10. Dasgupta, S.; Hossain, M.M.; Huq, M.; Wheeler, D. Climate change and soil salinity: The case of coastal Bangladesh. Ambio 2015, 44, 815-826. [CrossRef] [PubMed]

11. Evans, L.T.; Evans, L.T.; Evans, L.T. Feeding the Ten Billion: Plants and Population Growth; Cambridge University Press: Cambridge, UK, 1998.

12. McWilliam, J. The National and International Importance of Drought and Salinity Effects on Agricultural Production. Funct. Plant Biol. 1986, 13, 1-13. [CrossRef]

13. Mateo-Sagasta, J.; Burke, J.; FAO. Agriculture and water quality interactions: A global overview. In SOLAW Background Thematic Report-TR08; FAO: Rome, Italy, 2003.

14. Galli, V.; Messias, R.D.S.; Perin, E.C.; Borowski, J.M.; Bamberg, A.L.; Rombaldi, C.V. Mild salt stress improves strawberry fruit quality. LWT 2016, 73, 693-699. [CrossRef]

15. Grattan, S.; Grieve, C. Mineral element acquisition and growth response of plants grown in saline environments. Agric. Ecosyst. Environ. 1992, 38, 275-300. [CrossRef]

16. Azaizeh, H.; Steudle, E. Effects of Salinity on Water Transport of Excised Maize (Zea mays L.) Roots. Plant Physiol. 1991, 97, 1136-1145. [CrossRef]

17. Kao, W.Y.; Tsai, H.C.; Tsai, T.T. Effect of $\mathrm{NaCl}$ and nitrogen availability on growth and photosynthesis of seedlings of a mangrove species, Kandelia candel (L.) Druce. J. Plant Physiol. 2001, 158, 841-846. [CrossRef]

18. Sudhir, P.; Murthy, S. Effects of salt stress on basic processes of photosynthesis. Photosynthetica 2004, 42, 481-486. [CrossRef]

19. Chaves, M.M.; Flexas, J.; Pinheiro, C. Photosynthesis under drought and salt stress: Regulation mechanisms from whole plant to cell. Ann. Bot. 2009, 103, 551-560. [CrossRef] [PubMed]

20. Salim, M. Comparative Growth Responses and Ionic Relations of Four Cereals during Salt Stress. J. Agron. Crop. Sci. 1991, 166, 204-209. [CrossRef]

21. Dubey, R.S. Protein synthesis by plants under stress. In Handbook of Plant and Crop Stress; CRC Press: Boca Raton, FL, USA, 2010.

22. Villa-Castorena, M.; Ulery, A.L.; Catalán-Valencia, E.A.; Remmenga, M.D. Salinity and Nitrogen Rate Effects on the Growth and Yield of Chile Pepper Plants. Soil Sci. Soc. Am. J. 2003, 67, 1781. [CrossRef]

23. Fernández-Garcí, N.; Martinez, V.; Cerdá, A.; Carvajal, M. Fruit quality of grafted tomato plants grown under saline conditions. J. Hortic. Sci. Biotechnol. 2004, 79, 995-1001. [CrossRef]

24. Chadirin, Y.; Matsuoka, T.; Suhardiyanto, H. Application of Deep Sea Water for Multi-Trusses Cultivation of Tomato Using A Nutrient Film Technique. HAYATI J. Biosci. 2017, 15, 49-55. [CrossRef]

25. Colla, G.; Roupahel, Y.; Cardarelli, M.; Rea, E. Effect of Salinity on Yield, Fruit Quality, Leaf Gas Exchange, and Mineral Composition of Grafted Watermelon Plants. HortScience 2006, 41, 622-627. [CrossRef] 
26. Navarro, J.; Garrido, C.; Flores, P.; Martinez, V. The effect of salinity on yield and fruit quality of pepper grown in perlite. Span. J. Agric. Res. 2010, 8, 142. [CrossRef]

27. Djangsou, H.; Enrico, F.; Domenico, R.; Matteo, B. Blossom end-rot in tomato (Solanum lycopersicum L.): A multi-disciplinary overview of inducing factors and control strategies. Sci. Hortic. 2019, 249, 49-58.

28. Francois, L.E.; Youngs, V.L.; Maas, E.V.; Donovan, T.J. Effect of Salinity on Grain Yield and Quality, Vegetative Growth, and Germination of Semi-Dwarf and Durum Wheat1. Agron. J. 1986, 78, 1053-1058. [CrossRef]

29. Katerji, N.; Van Hoorn, J.; Fares, C.; Hamdy, A.; Mastrorilli, M.; Oweis, T. Salinity effect on grain quality of two durum wheat varieties differing in salt tolerance. Agric. Water Manag. 2005, 75, 85-91. [CrossRef]

30. Zheng, Y.; Xu, X.; Li, Z.; Yang, X.; Zhang, C.; Li, F.; Jiang, G. Differential Responses of Grain Yield and Quality to Salinity between Contrasting Winter Wheat Cultivars. Seed Sci. Technol. 2009, 3, 40-43.

31. Thitisaksakul, M.; Chun, A.; Tanadul, O.U.M.; Beckles, D.M.; Tananuwong, K.; Shoemaker, C.F.; Labavitch, J.M. Effects of Timing and Severity of Salinity Stress on Rice (Oryza sativa L.) Yield, Grain Composition, and Starch Functionality. J. Agric. Food Chem. 2015, 63, 2296-2304. [CrossRef] [PubMed]

32. Leogrande, R.; Vitti, C.; Lopedota, O.; Ventrella, D.; Montemurro, F. Effects of Irrigation Volume and Saline Water on Maize Yield and Soil in Southern Italy. Irrig. Drain. 2016, 65, 243-253. [CrossRef]

33. Abbas, G.; Saqib, M.; Rafique, Q.; Rahman, M.A.U.; Akhtar, J.; Haq, M.A.U.; Nasim, M. Effect of Irrigation and Nitrogen Levels on Grain Yield and Quality of Wheat (Triticum aestivum). Pak. J. Agric. Sci. 2013, 50, 185-189.

34. Rao, P.S.; Mishra, B.; Gupta, S. Effects of Soil Salinity and Alkalinity on Grain Quality of Tolerant, Semi-Tolerant and Sensitive Rice Genotypes. Rice Sci. 2013, 20, 284-291. [CrossRef]

35. Munns, R. The Impact of Salinity Stress. 2002. Available online: http://www.plantstress.com/articles/salinity i/salinity_i.htm (accessed on 6 April 2019).

36. Rontein, D.; Basset, G.; Hanson, A.D. Metabolic Engineering of Osmoprotectant Accumulation in Plants. Metab. Eng. 2002, 4, 49-56. [CrossRef]

37. Mujtaba, S.M.; Mughal, S.; Naqvi, M.H. Reclamation of Saline Soils through Biological Approaches. Business Recorder, 30 June 2003. Available online: https://epaper.brecorder.com/2019/06/03/1-page.html (accessed on 18 August 2019).

38. Govt of Pakistan, Finance Division, Economic Advisor's Wing, I. Economic Survey of Pakistan; DSpace BU Repository: Islamabad, Pakistan, 2003.

39. Szabolcs, I. Salt-Affected Soils; CRC Press: Boca Raton, FL, USA, 1989.

40. Zia-ur-Rehman, M.; Murtaza, G.; Qayyum, M.; Saifullah, S.M.; Akhtar, J. Salt-affected Soils: Sources, Genesis and Management. Soil Sci. Concepts Appl. 2016, 9, 190-216.

41. Nabi, G.; Azhar, F.M.; Khan, A.A. Genetic mechanisms controlling variation for salinity tolerance in upland cotton at plant maturity. Int. J. Agric. Biol. 2010, 12, 521-526.

42. Dagar, J. Soil Salinity Research in India: An Overview. Bull. Natl. Inst. Ecol. 2005, 15, 69-80.

43. CSSRI Vision-2020. CSSRI Perspective Plan. In Indian Council of Agricultural Research; Central Soil Salinity Research Institute: Karnal, India, 1997; p. 95.

44. Tyagi, N. Management of Salt-Affected Soils. In Fifty Years of Natural Resource Management Research; Singh, G.B., Sharma, B.R., Eds.; Indian Council of Agricultural Research: New Delhi, India, 1999; pp. 363-401.

45. Tyagi, N.K.; Rao, D.L.N. Salinity Research: Today and Tomorrow. Salinity Management in Agriculture; Gupta, S.K., Sharma, S.K., Taygi, N.K., Eds.; Central Soil Salinity Research Institute: Karnal, India, 2000; pp. 17-26.

46. Akbar, M.; Yabuno, T.; Nakao, S. Breeding for saline resistant varieties of rice. I. Variability for salt tolerance among some rice varieties. Jpn. J. Breed. 1972, 22, 272-284. [CrossRef]

47. Kingsbury, R.W.; Epstein, E. Selection for salt tolerance spring wheat. Crop Sci. 1984, 24, 310-315. [CrossRef]

48. Rana, R.S. Breeding Crop Varieties for Salt Affected Soil. In Breeding for Stress Resistance; Oxford and IBH: New Delhi, India, 1986.

49. Gad-El-Hak, M. Breeding a new variety of rice adapted to recently reclaim saline soils. Agric. Res. Rev. 1966, $44,1-13$.

50. Ashour, N.I.; Abd-El'Hamid, A.E.H.M. Relative salt tolerance of Egyptian cotton varieties during germination and early seedlings development. Plant Soil 1970, 33, 493-495. [CrossRef]

51. Jafri, A.Z.; Ahmad, R. Plant growth and ionic distribution in cotton (Gossypium hirsutum L.) under saline environment. Pak. J. Bot. 1994, 26, 105-114. 
52. Qadir, M.; Shams, M. Some Agronomic and Physiological Aspects of Salt Tolerance in Cotton (Gossypium hirsutum L.). J. Agron. Crop. Sci. 1997, 179, 101-106. [CrossRef]

53. Raja, S. Screening of tomato (Solanum lycopersicum L.) genotypes at different salinity levels. J. Plant Breed. Crop. Sci. 2012, 4, 94-100.

54. Nabi, G.; Shokat, S.; Azhar, M.T.; Azhar, F.M. Genetic basis of ion uptake and proline accumulation in Gossypium hirsutum L. Bulg. J. Agric. Sci. 2015, 21, 835-842.

55. Zafar, S.A.; Shokat, S.; Saddam, M.S.; Ahmed, H.G.M. Assessment of salinity tolerance in rice using seedling based morpho-physiological indices. Adv. Life Sci. 2015, 2, 142-149.

56. Glenn, E.P.; Jed Brown, J.; O'Leary, J.W. Irrigating Crops with Seawater. Sci. Am. 2009, 279, 76-81. [CrossRef]

57. Turnbull, J.W. Eucalyptus in Asia. In Proceedings of the International Conference, Zhanjiang, China, 7-11 April 2003.

58. Chipeta, M.E.; FAO-SFE. Eucalyptus in East Africa. The Socio-economic and Environmental Issues. Available online: http://www.fao.org/3/a-aq401e.pdf (accessed on 5 July 2019).

59. Aslam, Z.; Awan, A.R.; Rizwan, M.; Gulnaz, A.; Malik, K.A. Saline Agriculture Farmer Participatory Development Project. In Pakistan Punjab Component Terminal Report; Pakistan Atomic Energy Commission: Faisalabad, Pakistan, 2009.

60. Pessarakli, M.; Tucker, T.C. Uptake of N15 by cotton under salt stress. Soil Sci. Soc. Am. J. 1985, 49, $149-152$. [CrossRef]

61. Shaaban, M.M.; El-Fouly, M.M.; El-Zanaty; Abou El-Nour, A.A.; Abdel-Maguid, A.W. Halophytes and foliar fertilization as a useful technique for growing processing tomatoes in the saline affected soils. Pak. J. Biol. Sci. 2004, 7, 503-507.

62. Tester, M.; Davenport, R. Na+tolerance and Na+ transport in higher plants. Ann. Bot. 2003, 91, 503-527. [CrossRef] [PubMed]

63. Hadi, M.R.; Karimi, N. The Role of Calcium in Plants' Salt Tolerance. J. Plant Nutr. 2012, 35, $2037-2054$. [CrossRef]

64. Abbasi, G.; Akhtar, J.; Anwar-ul-Haq, M.; Ali, S.; Chen, Z.; Malik, W. Exogenous potassium differentially mitigates salt stress in tolerant and sensitive maize hybrids. Pak. J. Bot. 2014, 46, 135-146.

65. Yousuf, P.Y.; Ahmad, A.; Ganie, A.H.; Iqbal, M. Salt stress-induced modulations in the shoot proteome of Brassica juncea genotypes. Environ. Sci. Pollut. Res. 2016, 23, 2391-2401. [CrossRef] [PubMed]

66. Rashid, A.; Rafique, E.; Bhatti, A.U.; Ryan, J.; Bughio, N.; Yau, S.K. Boron Deficiency in Rainfed Wheat in Pakistan: Incidence, Spatial Variability and Management Strategies. J. Plant Nutr. 2011, 34, 600-613. [CrossRef]

67. Abid, M.; Khan, M.M.H.; Kanwal, M.; Sarfraz, M. Boron application mitigates salinity effects in canola (Brassica napus) under calcareous soil conditions. Int. J. Agric. Biol. 2014, 16, 1165-1170.

68. Abdel-Haliem, M.E.; Hegazy, H.S.; Hassan, N.S.; Naguib, D.M. Effect of silica ions and nano silica on rice plants under salinity stress. Ecol. Eng. 2017, 99, 282-289. [CrossRef]

69. Großkinsky, D.K.; Svensgaard, J.; Christensen, S.; Roitsch, T. Plant phenomics and the need for physiological phenotyping across scales to narrow the genotype-to-phenotype knowledge gap. J. Exp. Bot. 2015, 66, 5429-5440. [CrossRef]

70. Rush, D.W.; Epstein, E. Genotypic responses to salinity: Differences between salt-sensitive and salt-tolerant genotypes of the tomato. Plant Physiol. 1976, 57, 162-166. [CrossRef] [PubMed]

71. Flowers, T.J.; Troke, P.F.; Yeo, A.R. The Mechanism of Salt Tolerance in Halophytes. Annu. Rev. Plant Physiol. 1977, 28, 89-121. [CrossRef]

72. Tal, M.; Shannon, M.C. Salt tolerance in the wild relatives of the cultivated tomato: Responses of Lycopersicon esculentum, L. Cheesmanii, L. peruvianum, Solanum pennellii and F1 hybrids to high salinity. Aust. J. Plant Physiol. 1983, 10, 109-117. [CrossRef]

73. Noble, C.; Halloran, G.; West, D. Identification and selection for salt tolerance in lucerne (Medicago sativa L.). Aust. J. Agric. Res. 1984, 35, 239-252. [CrossRef]

74. Morgan, J.M. Osmotic Components and Properties Associated with Genotypic Differences in Osmoregulation in Wheat. Aust. J. Plant Physiol. 1992, 19, 67.

75. Shannon, M.C.; Gronwald, J.W.; Tal, M.M. Effects of salinity on growth and accumulation of organic and inorganic ions in cultivated and wild tomato species. J. Am. Soc. Hortic. Sci. 1987, 112, 416-423. 
76. Khan, A.A.; McNeilly, T.; Collins, J.C. Accumulation of amino acids, proline, and carbohydrates in response to aluminum and manganese stress in maize. J. Plant Nutr. 2000, 23, 1303-1314. [CrossRef]

77. Roy, D.; Basu, N.; Bhunia, A.; Banerjee, S.K. Counteraction of exogenous L-proline with NaCl in salt-sensitive cultivar of rice. Biol. Plant. 1993, 35, 69-72. [CrossRef]

78. Lauchli, A.; Epstein, E. Plant Responses to Saline and Sodic Conditions. In Agricultural Salinity Assessment and Management; ASCE: New York, NY, USA, 1990; pp. 113-137.

79. Turan, M.A.; Katkat, V.; Taban, S. Variations in Proline, Chlorophyll and Mineral Elements Contents of WheatPlants Grown under Salinity Stress. J. Agron. 2007, 6, 137-141.

80. Turan, M.A.; Katkat, V.; Taban, S. Salinity-Induced Stomatal Resistance, Proline, Chlorophyll and Ion Concentrations of Bean. Int. J. Agric. Res. 2007, 2, 483-488.

81. Harinasut, P.; Tsutsui, K.; Takabe, T.; Nomura, M.; Takabe, T.; Kishitani, S. Exogenous Glycinebetaine Accumulation and Increased Salt-tolerance in Rice Seedlings. Biosci. Biotechnol. Biochem. 1996, 60, 366-368. [CrossRef] [PubMed]

82. Cuin, T.A.; Betts, S.A.; Chalmandrier, R.; Shabala, S. A root's ability to retain K+correlates with salt tolerance in wheat. J. Exp. Bot. 2008, 59, 2697-2706. [CrossRef] [PubMed]

83. Stavridou, E.; Hastings, A.; Webster, R.J.; Robson, P.R.H. The impact of soil salinity on the yield, composition and physiology of the bioenergy grass Miscanthus $\times$ giganteus. GCB Bioenergy 2017, 9, 92-104. [CrossRef]

84. Darko, E.; Gierczik, K.; Hudák, O.; Forgó, P.; Pál, M.; Türkösi, E.; Kovács, V.; Dulai, S.; Majláth, I.; Molnár, I.; et al. Differing metabolic responses to salt stress in wheat-barley addition lines containing different $7 \mathrm{H}$ chromosomal fragments. PLoS ONE 2017, 12, 1-20. [CrossRef] [PubMed]

85. Bartoli, C.; Roux, F. Genome-Wide Association Studies in Plant Pathosystems: Toward an Ecological Genomics Approach. Front. Plant Sci. 2017, 8, 763. [CrossRef] [PubMed]

86. Gabriel, S.B.; Schaffner, S.F.; Nguyen, H.; Moore, J.M.; Roy, J.; Blumenstiel, B.; Higgins, J.; DeFelice, M.; Lochner, A.; Faggart, M.; et al. The Structure of Haplotype Blocks in the Human Genome. Science 2002, 296, 2225-2229. [CrossRef] [PubMed]

87. Singh, S.; Vikram, P.; Sehgal, D.; Burgueño, J.; Sharma, A.; Singh, S.K.; Sansaloni, C.P.; Joynson, R.; Brabbs, T.; Ortiz, C.; et al. Harnessing genetic potential of wheat germplasm banks through impact-oriented-prebreeding for future food and nutritional security. Sci. Rep. 2018, 8, 12527. [CrossRef]

88. Brachi, B.; Morris, G.P.; Borevitz, O.J. Genome-wide association studies in plants: The missing heritability is in the field. Genome Biol. 2011, 12, 232. [CrossRef]

89. Al-Tamimi, N.; Brien, C.; Oakey, H.; Berger, B.; Saade, S.; Ho, Y.S.; Schmöckel, S.M.; Tester, M.; Negrão, S. Salinity tolerance loci revealed in rice using high-throughput non-invasive phenotyping. Nat. Commun. 2016, 7, 13342. [CrossRef]

90. Xiao, Y.; Liu, H.; Wu, L.; Warburton, M.; Yan, J. Genome-wide Association Studies in Maize: Praise and Stargaze. Mol. Plant 2017, 10, 359-374. [CrossRef]

91. Angelovici, R.; Batushansky, A.; Deason, N.; Gonzalez-Jorge, S.; Gore, M.A.; Fait, A.; DellaPenna, D. Network-Guided GWAS Improves Identification of Genes Affecting Free Amino Acids. Plant Physiol. 2017, 173, 872-886. [CrossRef] [PubMed]

92. Liu, N.; Xue, Y.; Guo, Z.; Li, W.; Tang, J. Genome-Wide Association Study Identifies Candidate Genes for Starch Content Regulation in Maize Kernels. Front. Plant Sci. 2016, 7, 1046. [CrossRef] [PubMed]

93. Munns, R.; James, R.A.; Xu, B.; Athman, A.; Conn, S.J.; Jordans, C.; Byrt, C.S.; Hare, R.A.; Tyerman, S.D.; Tester, M.; et al. Wheat grain yield on saline soils is improved by an ancestral $\mathrm{Na}+$ transporter gene. Nat. Biotechnol. 2012, 30, 360-364. [CrossRef] [PubMed]

94. James, R.A.; Blake, C.; Zwart, A.B.; Hare, R.A.; Rathjen, A.J.; Munns, R. Impact of ancestral wheat sodium exclusion genes Nax1 and Nax2 on grain yield of durum wheat on saline soils. Funct. Plant Biol. 2012, 39, 609-618. [CrossRef]

95. Shi, H.; Zhu, J.K. Regulation of expression of the vacuolar $\mathrm{Na}+/ \mathrm{H}+$ antiporter gene AtNHX1 by salt stress and abscisic acid. Plant Mol. Biol. 2002, 50, 543-550. [CrossRef] [PubMed]

96. Yamaguchi, T.; Blumwald, E. Developing salt-tolerant crop plants: Challenges and opportunities. Trends Plant Sci. 2005, 10, 615-620. [CrossRef] [PubMed]

97. Xu, K.; Hong, P.; Luo, L.; Xia, T. Overexpression of AtNHX1, a vacuolar Na+/H+antiporter from arabidopsis thalina, in petunia hybrida enhances salt and drought tolerance. J. Plant Biol. 2009, 52, 453-461. [CrossRef] 
98. Osakabe, K.; Osakabe, Y.; Toki, S. Site-directed mutagenesis in Arabidopsis using custom-designed zinc finger nucleases. Proc. Natl. Acad. Sci. USA 2010, 107, 12034-12039. [CrossRef]

99. Sikora, E.; Arendt, T.; Bennett, M.; Narita, M. Impact of cellular senescence signature on ageing research. Ageing Res. Rev. 2011, 10, 146-152. [CrossRef]

100. Li, T.; Yang, X.; Yu, Y.; Si, X.; Zhai, X.; Zhang, H.; Dong, W.; Gao, C.; Xu, C. Domestication of wild tomato is accelerated by genome editing. Nat. Biotechnol. 2018, 36, 1160-1163. [CrossRef]

101. Zsögön, A.; Čermák, T.; Naves, E.R.; Notini, M.M.; Edel, K.H.; Weinl, S.; Freschi, L.; Voytas, D.F.; Kudla, J.; Peres, L.E.P. De novo domestication of wild tomato using genome editing. Nat. Biotechnol. 2018, 36, 1211-1216. [CrossRef] [PubMed]

102. Sánchez-León, S.; Gil-Humanes, J.; Ozuna, C.V.; Giménez, M.J.; Sousa, C.; Voytas, D.F.; Barro, F. Low-gluten, nontransgenic wheat engineered with CRISPR/Cas9. Plant Biotechnol. J. 2018, 16, 902-910. [CrossRef] [PubMed]

103. Arora, L.; Narula, A. Gene Editing and Crop Improvement Using CRISPR-Cas9 System. Front. Plant Sci. 2017, 8, 1932. [CrossRef] [PubMed]

104. James, R.A.; Davenport, R.J.; Munns, R. Physiological Characterization of Two Genes for Na+Exclusion in Durum Wheat, Nax1 and Nax2. Plant Physiol. 2006, 142, 1537-1547. [CrossRef] [PubMed]

105. Hirsch, R.E. A Role for the AKT1 Potassium Channel in Plant Nutrition. Science 1998, 280, 918-921. [CrossRef]

106. Deeken, R.; Sanders, C.; Ache, P.; Hedrich, R. Developmental and light-dependent regulation of a phloem-localised K+channel of Arabidopsis thaliana. Plant J. 2000, 23, 285-290. [CrossRef] [PubMed]

107. Wu, H.; Shabala, L.; Azzarello, E.; Huang, Y.; Pandolfi, C.; Su, N.; Wu, Q.; Cai, S.; Bazihizina, N.; Wang, L.; et al. $\mathrm{Na}+$ extrusion from the cytosol and tissue-specific $\mathrm{Na}+$ sequestration in roots confer differential salt stress tolerance between durum and bread wheat. J. Exp. Bot. 2018, 69, 3987-4001. [CrossRef]

108. Albacete, A.; Cantero-Navarro, E.; Großkinsky, D.K.; Arias, C.L.; Balibrea, M.E.; Bru, R.; Fragner, L.; Ghanem, M.E.; González, M.D.L.C.; Hernández, J.A.; et al. Ectopic overexpression of the cell wall invertase gene CIN1 leads to dehydration avoidance in tomato. J. Exp. Bot. 2015, 66, 3431-3432. [CrossRef]

109. Sessitsch, A.; Pfaffenbichler, N.; Mitter, B. Microbiome Applications from Lab to Field: Facing Complexity. Trends Plant Sci. 2019, 24, 194-198. [CrossRef]

110. Bagheri, A.A.; Saadatmand, S.; Niknam, V.; Nejadsatari, T.; Babaeizad, V. Effect of endophytic fungus, Piriformospora indica, on growth and activity of antioxidant enzymes of rice (Oryza sativa L.) under salinity stress. Int. J. Adv. Biol. Biomed. Res. 2013, 1, 1337-1350.

111. Baltruschat, H.; Fodor, J.; Harrach, B.D.; Niemczyk, E.; Barna, B.; Gullner, G.; Janeczko, A.; Kogel, K.H.; Schäfer, P.; Schwarczinger, I.; et al. Salt tolerance of barley induced by the root endophyte Piriformospora indica is associated with a strong increase in antioxidants. New Phytol. 2008, 180, 501-510. [CrossRef] [PubMed]

112. Li, L.; Li, L.; Wang, X.; Zhu, P.; Wu, H.; Qi, S. Plant growth-promoting endophyte Piriformospora indica alleviates salinity stress in Medicago truncatula. Plant Physiol. Biochem. 2017, 119, 211-223. [CrossRef] [PubMed]

113. Alikhani, M.; Khatabi, B.; Sepehri, M.; Nekouei, M.K.; Mardi, M.; Salekdeh, G.H. A proteomics approach to study the molecular basis of enhanced salt tolerance in barley (Hordeum vulgare L.) conferred by the root mutualistic fungus Piriformospora indica. Mol. BioSyst. 2013, 9, 1498. [CrossRef] [PubMed]

114. Helsel, Z.; Gond, S.; Torres, M.; Bergen, M.; White, J. Induction of salt tolerance and up-regulation of aquaporin genes in tropical corn by rhizobacterium Pantoea agglomerans. Lett. Appl. Microbiol. 2015, 60, 392-399.

115. Mayak, S.; Tirosh, T.; Glick, B.R. Plant growth-promoting bacteria confer resistance in tomato plants to salt stress. Plant Physiol. Biochem. 2004, 42, 565-572. [CrossRef] [PubMed]

116. Khan, A.L.; Waqas, M.; Asaf, S.; Kamran, M.; Shahzad, R.; Bilal, S.; Khan, M.A.; Kang, S.-M.; Kim, Y.-H.; Yun, B.-W.; et al. Plant growth-promoting endophyte Sphingomonas sp. LK11 alleviates salinity stress in Solanum pimpinellifolium. Environ. Exp. Bot 2017, 133, 58-69. [CrossRef]

117. Großkinsky, D.K.; van der Graaff, E.; Roitsch, T. Regulation of Abiotic and Biotic Stress Responses by Plant Hormones. In Plant Pathogen Resistance Biotechnology; Wiley: Hoboken, NJ, USA, 2016; pp. 131-154.

118. Großkinsky, D.K.; Petrášek, J. Auxins and cytokinins-The dynamic duo of growth-regulating phytohormones heading for new shores. New Phytol. 2019, 221, 1187-1190. [CrossRef] [PubMed] 
119. Egamberdieva, D. Alleviation of salt stress by plant growth regulators and IAA producing bacteria in wheat. Acta Physiol. Plant. 2009, 31, 861-864. [CrossRef]

120. Egamberdieva, D.; Jabborova, D.; Hashem, A. Pseudomonas induces salinity tolerance in cotton (Gossypium hirsutum) and resistance to Fusarium root rot through the modulation of indole-3-acetic acid. Saudi J. Biol. Sci. 2015, 22, 773-779. [CrossRef]

121. Shahzad, R.; Khan, A.L.; Bilal, S.; Waqas, M.; Kang, S.-M.; Lee, I.-J. Inoculation of abscisic acid-producing endophytic bacteria enhances salinity stress tolerance in Oryza sativa. Environ. Exp. Bot. 2017, 136, 68-77. [CrossRef]

122. Khan, A.L.; Hamayun, M.; Ahmad, N.; Hussain, J.; Kang, S.-M.; Kim, Y.-H.; Adnan, M.; Tang, D.-S.; Waqas, M.; Radhakrishnan, R.; et al. Salinity stress resistance offered by endophytic fungal interaction between Penicillium minioluteum LHL09 and Glycine max. L. J. Microbiol. Biotechnol. 2011, 21, 893-902. [CrossRef] [PubMed]

123. Khan, A.L.; Waqas, M.; Khan, A.R.; Hussain, J.; Kang, S.M.; Gilani, S.A.; Hamayun, M.; Shin, J.-H.; Kamran, M.; Al-Harrasi, A.; et al. Fungal endophyte Penicillium janthinellum LK5 improves growth of ABA-deficient tomato under salinity. World J. Microbiol. Biotechnol. 2013, 29, 2133-2144. [CrossRef] [PubMed]

124. Khan, A.L.; Waqas, M.; Lee, I.J. Resilience of Penicillium resedanum LK6 and exogenous gibberellin in improving Capsicum annuum growth under abiotic stresses. J. Plant Res. 2015, 128, 259-268. [CrossRef] [PubMed]

125. Qin, Y.; Druzhinina, I.S.; Pan, X.; Yuan, Z. Microbially Mediated Plant Salt Tolerance and Microbiome-based Solutions for Saline Agriculture. Biotechnol. Adv. 2016, 34, 1245-1259. [CrossRef] [PubMed]

126. Großkinsky, D.K.; Tafner, R.; Moreno, M.V.; Stenglein, S.A.; De Salamone, I.E.G.; Nelson, L.M.; Novak, O.; Strnad, M.; Van Der Graaff, E.; Roitsch, T. Cytokinin production by Pseudomonas fluorescens G20-18 determines biocontrol activity against Pseudomonas syringae in Arabidopsis. Sci. Rep. 2016, 6, 23310. [CrossRef]

127. Liu, F.; Xing, S.; Ma, H.; Du, Z.; Ma, B. Cytokinin-producing, plant growth-promoting rhizobacteria that confer resistance to drought stress in Platycladus orientalis container seedlings. Appl. Microbiol. Biotechnol. 2013, 97, 9155-9164. [CrossRef] [PubMed]

128. Großkinsky, D.K.; Edelsbrunner, K.; Pfeifhofer, H.; van der Graaff, E.; Roitsch, T. Cis- and trans-zeatin differentially modulate plant immunity. Plant Signal. Behav. 2013, 8, e24798. [CrossRef]

129. Arkhipova, T.N.; Veselov, S.U.; Melentiev, A.I.; Martynenko, E.V.; Kudoyarova, G.R. Ability of bacterium Bacillus subtilis to produce cytokinins and to influence the growth and endogenous hormone content of lettuce plants. Plant Soil 2005, 272, 201-209. [CrossRef]

130. Ortíz-Castro, R.; Valencia-Cantero, E.; López-Bucio, J. Plant growth promotion by Bacillus megaterium involves cytokinin signaling. Plant Signal. Behav. 2008, 3, 263-265. [CrossRef]

131. Parnell, J.J.; Berka, R.; Young, H.A.; Sturino, J.M.; Kang, Y.; Barnhart, D.M.; Dileo, M.V. From the Lab to the Farm: An Industrial Perspective of Plant Beneficial Microorganisms. Front. Plant Sci. 2016, 7, 8672. [CrossRef]

132. Shrivastava, P.; Kumar, R. Soil salinity: A serious environmental issue and plant growth promoting bacteria as one of the tools for its alleviation. Saudi J. Biol. Sci. 2015, 22, 123-131. [CrossRef] [PubMed]

133. Bhattacharyya, P.N.; Goswami, M.P.; Bhattacharyya, L.H. Perspective of beneficial microbes in agriculture under changing climatic scenario: A review. J. Phytol. 2016, 8, 26. [CrossRef]

134. Machado, R.M.A.; Serralheiro, R.P. Soil Salinity: Effect on Vegetable Crop Growth. Management Practices to Prevent and Mitigate Soil Salinization. Horticulturae 2017, 3, 30. [CrossRef]

135. Aydin, A. Humic acid application alleviate salinity stress of bean (Phaseolus vulgaris L.) plants decreasing membrane leakage. Afr. J. Agric. Res. 2012, 7, 1073-1086. [CrossRef]

136. Bargaz, A.; Nassar, R.M.A.; Rady, M.M.; Gaballah, M.S.; Thompson, S.M.; Brestic, M.; Schmidhalter, U.; Abdelhamid, M.T.; Abdelhamid, M. Improved Salinity Tolerance by Phosphorus Fertilizer in Two Phaseolus vulgaris Recombinant Inbred Lines Contrasting in Their P-Efficiency. J. Agron. Crop. Sci. 2016, 202, 497-507. [CrossRef]

137. Bacilio, M.; Moreno, M.; Bashan, Y. Mitigation of negative effects of progressive soil salinity gradients by application of humic acids and inoculation with Pseudomonas stutzeri in a salt-tolerant and a salt-susceptible pepper. Appl. Soil Ecol. 2016, 107, 394-404. [CrossRef] 
138. Kaya, C.; Tuna, A.L.; Ashraf, M.; Altunlu, H. Improved salt tolerance of melon (Cucumis melo L.) by the addition of proline and potassium nitrate. Environ. Exp. Bot. 2007, 60, 397-403. [CrossRef]

139. Martinez, V.; Cerdá, A. Influence of $\mathrm{N}$ source on rate of $\mathrm{Cl}, \mathrm{N}, \mathrm{Na}$ and $\mathrm{K}$ uptake by cucumber seedling grown in saline condition. J. Plant Nutr. 1989, 12, 971-983. [CrossRef]

140. Romero-Aranda, M.R.; Jurado, O.; Cuartero, J. Silicon alleviates the deleterious salt effect on tomato plant growth by improving plant water status. J. Plant Physiol. 2006, 163, 847-855. [CrossRef]

141. Karlidag, H.; Yildirim, E.; Turan, M. Salicylic acid ameliorates the adverse effect of salt stress on strawberry. Sci. Agricola 2009, 66, 180-187. [CrossRef]

142. Savvas, D.; Giotis, D.; Chatzieustratiou, E.; Bakea, M.; Patakioutas, G. Silicon supply in soilless cultivations of zucchini alleviates stress induced by salinity and powdery mildew infections. Environ. Exp. Bot. 2009, 65, 11-17. [CrossRef]

143. Ma, X.; Zheng, J.; Zhang, X.; Hu, Q.; Qian, R. Salicylic Acid Alleviates the Adverse Effects of Salt Stress on Dianthus superbus (Caryophyllaceae) by Activating Photosynthesis, Protecting Morphological Structure, and Enhancing the Antioxidant System. Front. Plant Sci. 2017, 8, 685. [CrossRef]

144. Brouwer, C.; Goffeau, A.; Heibloem, M. Irrigation Water Management; Food and Agriculture Organization: Rome, Italy, 1985.

145. Malash, N.M.; Flowers, T.J.; Ragab, R. Effect of irrigation methods, management and salinity of irrigation water on tomato yield, soil moisture and salinity distribution. Irrig. Sci. 2008, 26, 313-323. [CrossRef]

146. Lamm, F.R. Cotton, Tomato, Corn, and Onion Production with Subsurface Drip Irrigation: A Review. Trans. $A S A B E$ 2016, 59, 263-278.

(C) 2019 by the authors. Licensee MDPI, Basel, Switzerland. This article is an open access article distributed under the terms and conditions of the Creative Commons Attribution (CC BY) license (http://creativecommons.org/licenses/by/4.0/). 